\title{
KIT NP_000213.1:p.G648D
}

National Cancer Institute

\section{Source}

National Cancer Institute. KIT NP 000213.1:p.G648D. NCI Thesaurus. Code C155684.

A change in the amino acid residue at position 648 in the mast/stem cell growth factor receptor Kit protein where glycine has been replaced by aspartic acid. 